\title{
The Prognostics for Credit Shocks (Financial Crisis) and Insights for Mitigating Consequences
}

\author{
Vytautas Snieska, Vitalija Venckuviene, Ruta Masteikiene
}

Kaunas University of Technology

K. Donelaicio st. 73, LT-44029, Kaunas, Lithuania

E-mail.vytautas.snieska@ktu.lt,vitalija.venckuviene@ktu.lt,ruta.masteikiene@ktu.lt

cross $^{\text {ref }}$ http://dx.doi.org/10.5755/j01.ee.27.1.9533

Credit shocks are organic phenomena in economy but extreme biases could have harm effect both at micro and macro level. Many econometric models have been constructed based on various theoretical approaches (neoclassical economics, Keynesian, business cycle, post Keynesian and others) aiming to predict peaks and pitfalls in the economies. But unfortunately many of them were misleading in predicting 2007-2008 financial crisis and long lasting recession afterwards. The literature indicates plenty of negative aspects of recent financial crisis at macro-level including decrease in consumption, aggregate demand and investment, financial markets 'stagnation, increase in Government debt and unemployment rate and even more political instability. While effects at micro level encompass the decline in business loans, fall in equity value, property devaluation, decrease in sales, increase in defaults, decrease in investment in $R \& D$ and etc. Especially small open economies, like Lithuania, have suffered most in terms of shrinkage of GDP during the 2007-2009 period. Therefore the qualitative approach is valuable in deepening the knowledge about the preconditions and consequences of credit shocks. Thus this study aims to extract the main prerequisites and outcomes for credit shocks and to approve it by the expert opinion. Expert evaluation results indicate that absence of reserve funds was the most important precondition for 2007-2008 crisis and recession. Moreover when the gathered unplanned cyclical income have been wasted and even more the public sector spending has been increased that led to even bigger budget deficit.

Also experts unanimously identified the main consequences of credit shock and 2007-2009 crisis including: (1) Decrease in GDP and government revenues, (2) Fall in domestic demand in Lithuania and increase in importance of exports for economic development, (3) The decline in consumption level and the delay of purchase, and (4) Shrinkage of construction sector, and manufacturing and trade of durable goods.

Keywords: Credit Shock, Recession, Financial Crisis, Small Open Economy, Expert Evaluation.

\section{Introduction}

Volumes are written on the recent economic crisis issues including the critiques for econometric models based on various theoretical approaches (like neoclassical economics, Keynesian, business cycle, post Keynesian and others) which intended to predict economicfluctuations but unfortunately mislead. Keen (2013) notes that from the list provided by Bezemer (2009), the analysts representing Post-Keynesian school (Stephen Keen and Wynne Godley) were those who predicted the financial crisis. Having in mind many critiques for macroeconomic models, this research therefore focuses on in-depth analysis of factors and consequences for economic crises, by implementing the popular method in social sciences like expert evaluation.

Various issues on the 2007-2008 global financial crises are the headlines on many research papers specifically dealing with the factors of credit shocks, and estimating its effect on economies (Gilchrist \& Zakrajsek, 2012; Pesaran \& Xu, 2013; Fornari \& Stracca, 2011; Maredza \& Ikhide, 2013; Bedock \& Stevanovic, 2012) indicating the relevance of the topic.

Efforts have been taken to understand the main factors and consequences for such tremendous worldwide recession wave (Eickmeier \& Ng, 2011; Bassett et al., 2013; Liberti \& Sturgess, 2013; Khan \& Thomas, 2013; Gilchrist \& Zakrajsek, 2012; Amiti \& Weinstein, 2013;
Claessens, Tong \& Zuccardi, 2012; Pesaran \& Xu, 2013; Greenstone \& Mas, 2012) although fragmentary.

Recent research identifies bank liquidity and credit shocks as the core factors of 2007-2008 financial crises (Liberti \& Sturgess, 2013). For instance, results by Meeks (2009) research indicate that credit shocks are related to decline in output prices and policy rates. Therefore the research problem arises - what are the main factors and consequences of credit shocks to small and open economy?

The aim of this article is to explore the factors and consequences of credit shocks focusing on the small open economy case by employing the qualitative research method.

Lithuania has features of small open economy. As noticed by Umbrasiene (2014) the openness ratio has gradually increased from 1.22 in 2005 till 1.57 in 2011 . This suggests that its economy is sensitive to global economic fluctuations (Umbrasiene, 2014), and actually Lithuania has experienced deep recession including decrease in aggregate demand, shrinkage of domestic markets especially real estate and construction, stagnation of financial markets, etc. To illustrate, percentage growth of real GDP during the 2007-2011 decreased dramatically: 9.8 percent (in 2007), 2.9 percent (in 2008), -14.8 percent (in 2009) (Finansu ministerija, 2011). 
Therefore, in order to overcome the negative effects of financial fluctuations in the future, the in-depth analysis of prerequisites and consequences of financial crisis is necessary.

The methods employed in this article are as follow: systematic and logical literature analysis, expert (opinion) evaluation research method.

\section{Effect of Credit Supply and Demand Shocks on Economy: Theoretical Framework}

This section presents analysis of main prerequisites and outcomes of credit shocks as identified in the theoretical discourse, based on this the empirical research (experts' evaluation research) have been constructed.

Carnot, Koen and Tissot (2011) notice that "financial stability dimension" was a distinguish feature of 2007-2008 crisis and more over it was specific for financial institutions for instance in the US (for example Lehman Brothers). Moreover research by Friese (2011) indicates, that "The main underlying causes were identified to be the same by the various actors: changes in the structure of financial markets, accompanied by the introduction of new innovative financial products and the credit bubble." (Friese, 2011).

After having carried an analysis of the international discourse (Claessens \& Zuccardi, 2012; Cohan, 2010; Federal Reserve Bank of New York, 2010; Gianone et al., 2011; Gilchrist, Yankov \& Zakrajsek, 2009; Greenstone \& Mas, 2012; Ho, 2010; Lagarde, 2011; Liberti \& Sturgess, 2013) on the causes of credit supply and demand shocks, several important aspects could be pointed out:

- The problem of asymmetric information. The asymmetry between borrowers and lenders available information creates preconditions for the loss of financial stability;

- A high level risk lending. Growing levels of lending to borrowers whose risk is not covered by insurance, can cause significant systemic risks and may create preconditions for the negative effects;

- A high level of integration of financial groups in the European Union may contribute to the risks and adverse effects spread to other countries;

- Insufficient supervision of financial institutions. Up to 2008 financial institutions did not have enough incentives to better identify hidden risks attributed to the issues of credits and internalize the respective costs;

- Adjustable-Rate Mortgages. At low interest rates and easy credit conditions, many residents usually acquire real estate with an overvalued price and without estimation of they can afford it. Following the rise in interest rates, many borrowers can no longer cover the cost of credit and banks are forced to take over the real estate.

- The ignorance of the counter-cyclical measures. Before the 2008 credit market shock the governments of many countries have not taken sufficient measures, which would act counter-cyclically in the period of the rising economy, especially when there is a noticeable overall credit growth. It would have reduced asset price bubble and its subsequent burst risk;

- Regulatory environment options. Since the year 2000 many countries have taken measures to deal with the political risks arising from unsafe excessive lending growth, but many of them were ineffective, mainly because of the choice possibility of more favourable regulatory options;

- Speculation. During the period of the economic growth, because of commercial banks adopted policies and easy access to credit for borrowers, many investors believe that their acquired asset value will increase. This leads many new investors to get additional loans on concessional terms (eg., low or zero initial advances, and / or minor requirements of the borrower's creditworthiness). Sudden spikes in asset prices (eg. 2007 real estate.) encourage investors to invest in insecure and precarious projects. In the period of the investment boom, property prices reach record highs and imply preconditions for a new credit market shock.

- Changes in exchange rates. The total EU financial system should be more resilient to adverse changes in exchange rates that have negative impacts on the ability of borrowers to pay their debts denominated in foreign currencies.

Furthermore, volumes have been written in analysing the issues of credit shocks and financial crises. The literature analyses indicate the credit supply and credit demand shocks. For instance analysis by Barnett and Thomas (2013) indicates that "credit supply shocks can account for most of the weakness in bank lending" moreover they conclude that ,credit supply shocks appear to behave more like aggregate supply shocks than aggregate demand shocks because they cause output and inflation to move in opposite directions" (Barnett \& Thomas, 2013).

Various research has been taken in order to explore the different effect of 2007-2008 financial crisis on macro and micro level as well. According to Bassett et al. (2013) „Identifying macroeconomic effects of credit shocks is difficult because many of the same factors that influence the supply of loans also affect the demand for credit".

Tracey (2007) outlines the model that aims to predict changes in loan quality. The findings suggest that monetary and structural factors are essential for the accumulation of non-performing loans (Tracey, 2007).

For instance, Liberti and Sturgess (2013) investigate a credit supply shock and its effect on the small and medium sized firm lending division of a large multinational bank operating in emerging economies. According to their results " (...) collateral, and in particular nonspecific collateral, is a channel through which borrowers can mitigate bank-specific lending channel effects without turning to alternate lenders in the credit market." (Liberti $\&$ Sturgess, 2013).

Literature analysis indicate, that "Tightening shocks to this credit supply indicator lead to a substantial decline in output and the capacity of businesses and households to borrow from banks, as well as to a widening of credit spreads and an easing of monetary policy." (Bassett et al., 2013).

Eickmeier and $\mathrm{Ng}$ (2011) have studied the effect of credit supply shocks in the US to the euro area and Japan. They have employed GVAR model and the findings indicate that "(...) negative US credit supply shocks in particular have strong negative effects on GDP in foreign 
countries, explaining up to a quarter of forecast error variance in the medium run." (Eickmeier \& Ng, 2011).

Jermann and Quadrini (2012) have presented a model in which the recent crisis effect reveals as a tightening of firms' financing conditions that have caused a sharp downturn in GDP (and labour) starting in the second half of 2008 .

Khan and Thomas (2013) model shows that credit shocks are related to reduction in aggregate total factor of productivity, they contend that "(...) a shock to the availability of credit can, on its own, generate a large and protracted recession, because it induces changes in the distribution of firms."

Gilchrist and Zakrajsek (2012) have studied the relation between credit supply conditions and bank lending, they find evidences that shocks can lead economy to stagnation, they suggest that " (...) shocks to the excess bond premium lead to a pronounced and protracted contraction in economic activity, a decline in nominal interest rates, a sharp fall in equity valuations, and an eventual decline in business loans outstanding“. The association was found between changes in credit supply conditions and unused commitments and loans outstanding (Gilchrist \& Zakrajsek, 2012).

Paravisini, Rappoport, Schnabl and Wolfenzon (2010) analyse the effect of credit supply shocks on exports. According to their findings export volume is very sensitive to the change in credit supply, “(...) but does not significantly affect the number of firms entering an export market" (Paravisini et al., 2010). In addition findings by Amiti and Weinstein (2013) have revealed that export revenues are not elastic - “(..) in ,normal times", when credit temporally drops, firms may adjust their total production, but on average they do not vary their exports." (Amiti \& Weinstein, 2013). Moreover they provided empirical evidences that shock to the credit supply affect borrower investment rates (Amiti \& Weinstein, 2013).

Following the above given literature analysis the theoretical framework was constructed and is outlined in the figure below (figure 1).

\section{PRECONDITIONS}

-Asymmetric information

-High level of risk lending;

-The European Union's

integration of financial groups;

-Lack of supervision of financial

institutions;

-Floating interest real estate

loans (mortgages);

-Counter-cyclical measures

-Regulatory arbitrage options;

-Speculation;

-Exchange rate changes.

-Financial globalization;

-Gold price boom

-Oil price shock

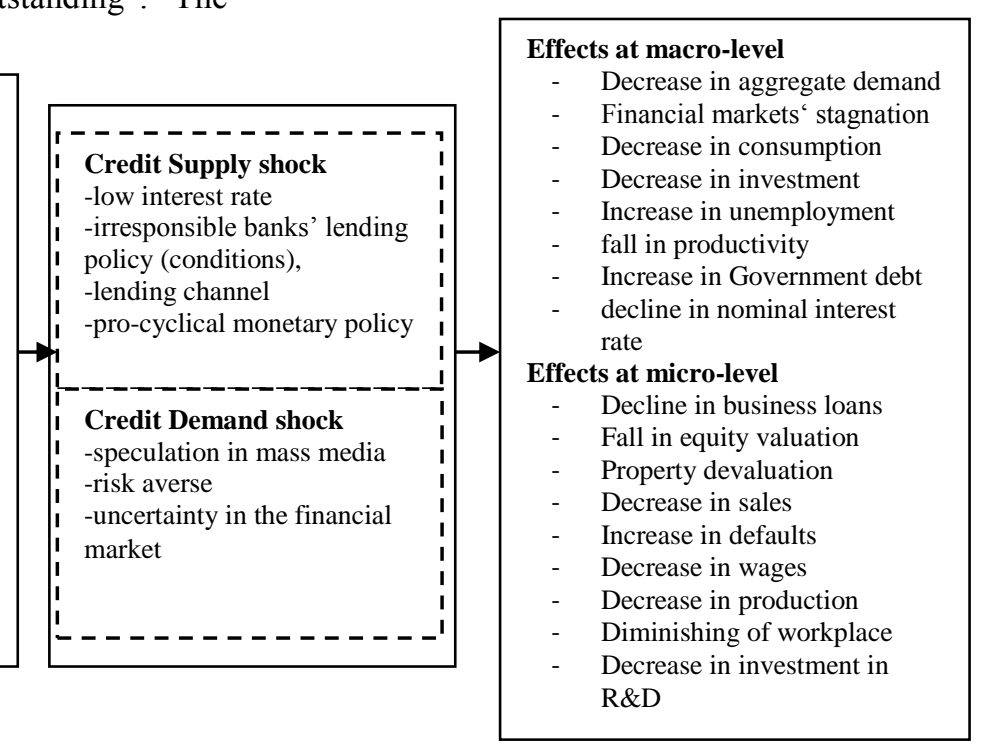

Figure 1. Theoretical framework of preconditions and consequences for the credit shocks

To sum up, literature indicates plenty of negative aspects of recent financial crisis at macro-level including decrease in consumption, aggregate demand and investment, financial markets ${ }^{6}$ stagnation, increase in Government debt and unemployment rate and even more political instability. While effects at macro level encompass the decline in business loans, fall in equity valuation, property devaluation, decrease in sales, increase in defaults, decrease in investment in $R \& D$ and etc. The framework shows credit shocks effects on micro and macro levels. It is difficult to identify negatives and positive effects, because for different subjects different effects are achieved. Only the overall economic situation indicates the negative or positive features and which policy incentives to implement in order to achieve macroprudency for stable economy.

According to the framework the questionnaire for the expert evaluation research was constructed. The following chapter presents the empirical investigation based on qualitative research approach.

\section{Data and Methodology}

In order to explore the main preconditions and outcomes for the credit shocks and 2007-2009 crises the expert evaluation method have been chosen. Having in mind that many econometric models had failed in predicting the economic fluctuations, some implications arises, for instance what are the qualitative dimensions of factors determining the credit shocks, what are possible outcomes, thus the experts from financial sector and other institutions were inquired.

Expert evaluation method is useful when there is a need of deep analysis, and qualitative aspects of subjects are present. Moreover, as have been argued by MacCarthy and Atthirawong (2003), the most important is the selection of experts and to assess their competence and not to give priority to the quantity of the respondents, but higher degree of excellence. In addition, as noted by the same authors, it is very important to make sure that the experts do not affect each other's opinion. 
In the current research the questionnaire was spread to representatives from financial sector, economists and Lithuanian free market institute experts. In the end, 9 experts agreed to fill the questionnaire.

The main research instrument is a questionnaire, which consists of three extensive questions blocks. Experts had to assess the given statements in a five point Likert type scale, 1 indicates that experts disagree with the statement, while 5 indicates full support for the statements.

The instrument for expert evaluation research grounded in scientific literature results so far. Mainly three blocks of questions have been constructed:

- 1 st block - preconditions for credit shocks; eleven sub-questions (statements) embedded;

- 2nd block - outcomes of credit shocks; consist of fourteen sub-questions (statements);

- 3 rd block - instruments for diminishing negative outcomes; consist of fourteen sub-questions (statements).

The structure of research was set up as recommended by methodologists (Field, 2009; Sheskin, 2000) and presented in figure 2 .

Exploratory data analysis. Firstly the initial data analysis, the initial data analysis was proceeded due to inspection of normality, outliers and etc. For this purpose the descriptive statistics table have been inspected.

Questionnaire reliability calculation. The primary data were processed with the Statistical Package for Social Sciences (SPSS 17.0). The analysed data are in five point Likert scale, therefore the data type is interval, and the procedures have been employed referring to this assumption. After the exploratory data analysis the reliability of instrument (questionnaire) has been conducted and Cronbach alpha $(\alpha)$ has been computed. As it is indicated in methodologists' literature Cronbach alpha is a popular metric in social sciences to measure internal consistency of the questionnaire, which is also known as reliability (Yang \& Green, 2011; Raja Prasad \& Reghunath, 2010; Calaguas \& Dizon, 2011). The parameter $\alpha$ vary from 0 to 1 inclusively. Many scientists (Raja Prasad \& Reghunath, 2010; Calaguas \& Dizon, 2011) have cited interpretation of Cronbach alpha values as provided by George and Mallery (2003): _> .9 - Excellent, _> .8 - Good, _> .7 - Acceptable, _> .6 - questionable _> .5 - bad and _ $<.5$ - is unacceptable. Usually the threshold of 0.7 for social science research is defined meaning that the questionnaire items measure the same object (Vogt \& Johnson, 2011). In this research the Cronbach alpha critical value of 0.7 has been set up. Having in mind that the questionnaire was made up of three blocks of questions, the Cronbach alpha have been computed for each question block, and at the end the overall mean alpha has been computed.

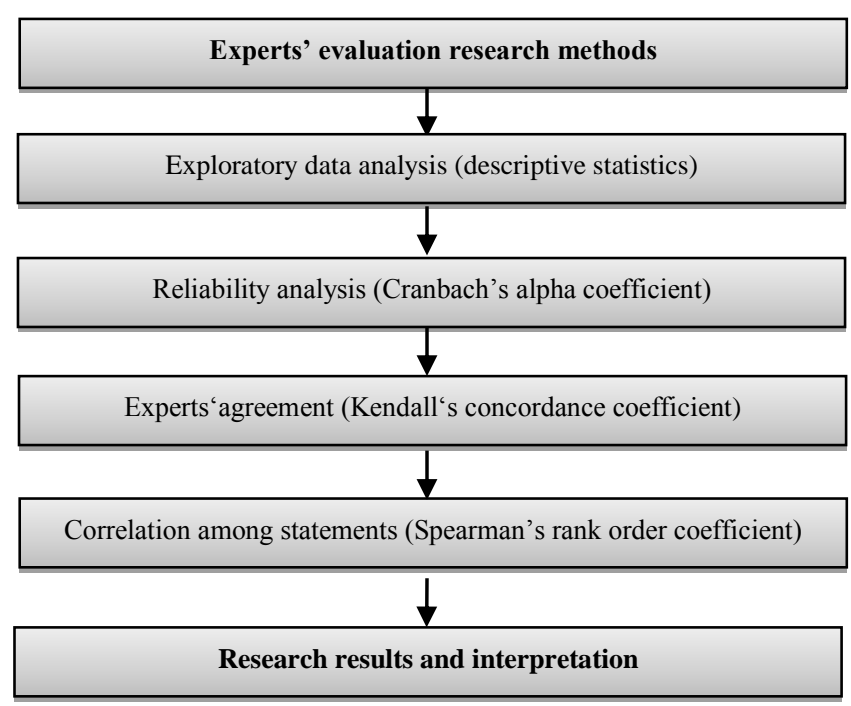

Figure 2. Research sequence/framework

Expert agreement evaluation. After the assessment of the reliability of the questionnaire have been done, agreements of expert opinions have been computed (see figure 2.). For this purpose the Kendall's coefficient of concordance (W) is employed. Kendall's coefficient of concordance is a measure that allows a researcher to evaluate the degree of agreement between $\mathrm{m}$ sets of ranks for $\mathrm{n}$ subjects/objects (Sheskin, 2000). While calculating the concordance of experts' opinion the statistical hypothesis about significance of $\mathrm{W}$ is tested ( $\mathrm{H}$ null: $\mathrm{W}=0$; alternative $\mathrm{H}$ : $\mathrm{W}^{\mp} 0$ ). This is shown by examining p-value; the critical threshold for $\mathrm{p}$-value is 0.05 . If the $\mathrm{p}$-value $<0.05$, then $\mathrm{W}$ significantly different from 0 and the compatibility level is sufficiently reliable.

The methodologists discuss about the critical values for Kendall's $W$. The computed $W$ in this research will be interpreted according Schmidt (1997): where $W$ of 0.1 indicates "Very weak agreement" and no confidence in Ranks; 0.3 - Weak agreement and Low confidence in ranks; 0.5 - "Moderate agreement" and fair confidence in ranks, 0.7 - "Strong agreement" and high confidence in ranks.

Spearman's Rank-Order Correlation Coefficient (here and after Spearman's rho) was calculated in order to find a relation among the statements' ratings. It is a nonparametric measure of association/correlation which usually is employed with ordinal data (Sheskin, 2000). The main hypothesis which Spearman's Rank-Order Correlation Coefficient - "is there a significant monotonic relationship between the two variables" (Sheskin, 2000). Sheskin (2000) provides a definition of monotonic relationship: "A relationship between two variables is monotonic increasing, if an increase in the value of one variable is always accompanied by an increase in the value of the other variable. A relationship between two variables is monotonic decreasing, if an increase in the value of one variable is always accompanied by a decrease in the value of the other variable. Based on the above definitions, a positively sloped straight line represents an example of a monotonic increasing function, while a negatively sloped straight line represents an example of a monotonic decreasing function" (Sheskin, 2000, p.372). 


\section{Data Analysis and Interpretation}

Results of reliability analysis are presented in table 1 . As the table reads the reliability coefficient alpha is acceptable for each question block as the computed Cronbach's alpha parameters have passed the threshold of 0.7 .

In order to assess the compatibility of experts' opinion nonparametric statistical tests (Friedman and Kendall's concordance test) have been conducted.

While analysing the expert compatibility regarding the preconditions for credit shocks Kendall concordance coefficient tests have been conducted to test whether there were statistically significant difference in ranks (table 2).
Reliability Statistics for three questions' blocks

\begin{tabular}{|l|c|c|}
\hline & Cronbach's Alpha & N of Items \\
\hline $\begin{array}{l}1^{\text {st }} \text { block-preconditions for } \\
\text { credit shocks }\end{array}$ & 0.770 & 11 \\
\hline $2^{\text {nd }}$ block- outcomes & 0.793 & 14 \\
\hline $\begin{array}{l}3^{\text {rd }} \text { block-instruments for } \\
\text { diminishing negative } \\
\text { outcomes }\end{array}$ & 0.893 & 14 \\
\hline $\begin{array}{l}\text { Arithmetic mean of } \\
\text { Cronbach's Alpha }\end{array}$ & $\mathbf{0 . 8 1 9}$ & \\
\hline
\end{tabular}

A moderate and significant compatibility among experts ratings have been found, as indicated by average Kendall concordance coefficient value $(\mathrm{W}=0.446)$ and $\mathrm{p}$-value $(0.000<0.05)$, meaning the significant difference among ranks (see figure 3 ).

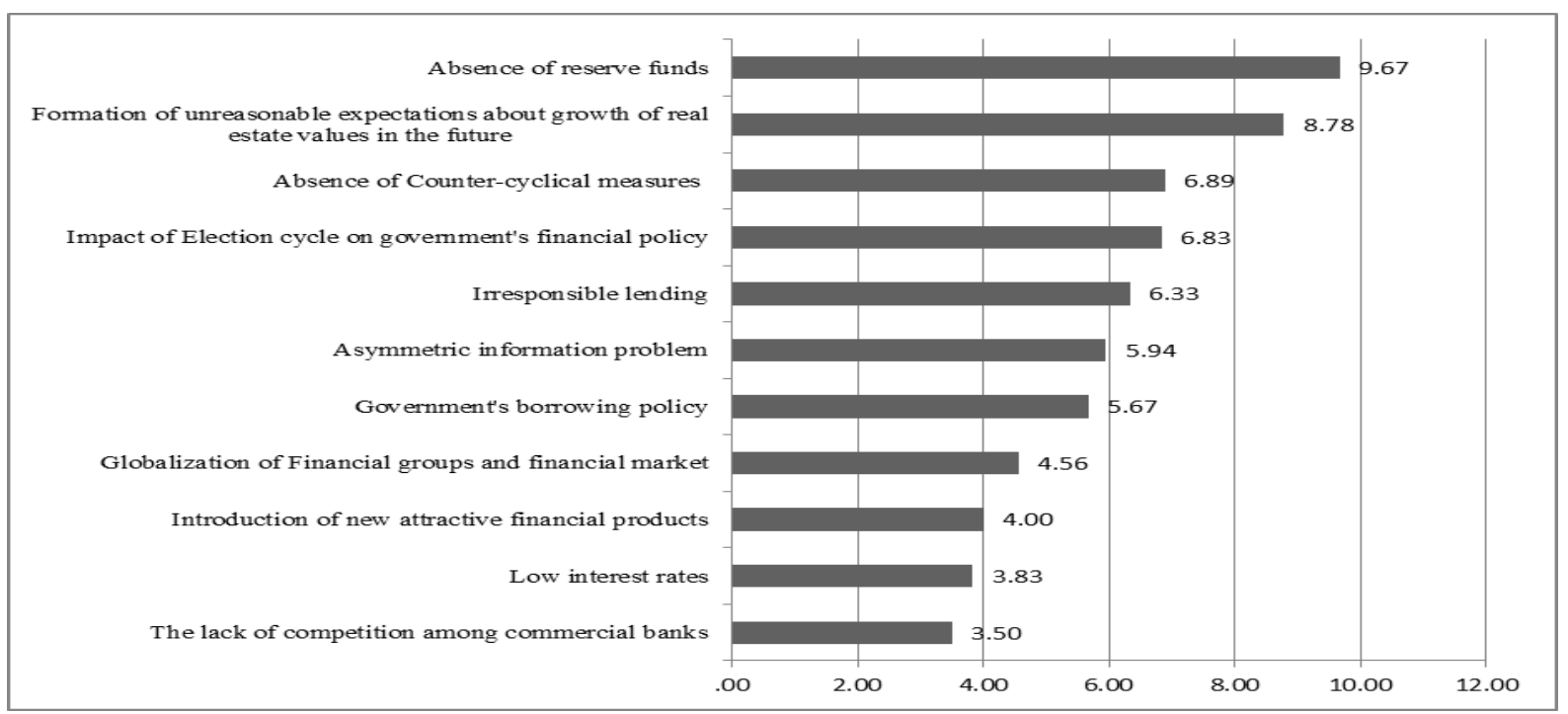

Figure 3. Mean ranks for statements indicating preconditions for 2007-2009 crisis

According to the ranks given by experts' absence of reserve funds (mean rank of 9.67) was the most important precondition for 2007-2009 crisis, especially when the gathered unplanned cyclical income have been wasted and even more the public sector spending has been increased that led to even bigger budget deficit.

The second important precondition was formation of unreasonable expectations about the future real estate prices (mean rank of 8.78). It worth noticing that during the economic growth period both banks policy easily issue credits for real estate and lack of consumer awareness were main constituents for boom in the market.

Less important precondition for 2007-2009 crises as indicated by experts' were Absence of Counter-cyclical measures (mean rank of 6.89) and Impact of Election cycle on government's financial policy (mean rank of 6.83), Irresponsible lending (mean rank of 6.33) as well (see figure 3.)

Interesting to notice that according to experts globalization of financial groups and financial market, was not primary precondition for 2007-2009 crisis, whilst the literature analysis (for instance, Schnabl (2008)) indicate that this factor could cause the deep recession afterward and spread over many countries (see figure 3.). Moreover according to experts ratings (see figure 3.), Low interest rates (mean rank of 3.83) and lack of competition among commercial banks (mean rank of 3.50) were least important factors for 2007-2009 crises.

When considering the correlations among the preconditions for the credit shock and financial crisis a few significant monotonic relationships have been found. The statistically significant correlations are presented in the table 2 .

Table 2

Correlations among preconditions for credit shocks and financial crisis (Spearman's rho)

\begin{tabular}{|l|c|c|}
\hline & $\begin{array}{c}\text { Asymmetric } \\
\text { information problem } \\
\text { (Correlation } \\
\text { Coefficient, Sig. (2- } \\
\text { tailed)) }\end{array}$ & $\begin{array}{c}\text { Introduction of new } \\
\text { attractive financial } \\
\text { products (Correlation } \\
\text { Coefficient, Sig. (2- } \\
\text { tailed)) }\end{array}$ \\
\hline Irresponsible lending & $\mathbf{0 . 8 6 8 *}$ & 0.534 \\
0.002 & .138 \\
\hline Introduction of new & $\mathbf{0 . 7 6 4}$ & 1.000 \\
attractive financial products & $\mathbf{0 . 0 1 7}$ &. \\
\hline $\begin{array}{l}\text { Globalization of Financial } \\
\text { groups and financial market }\end{array}$ & 0.523 & $\mathbf{0 . 8 9 9}$ \\
\hline
\end{tabular}

**. Correlation is significant at the 0.01 level (2-tailed).

*. Correlation is significant at the 0.05 level (2-tailed). 
A strong positive relationship (Spearman's rho 0.868, $p=0.002$ ) was found between Asymmetric information and Irresponsible lending. It does not mean that one can cause another it rather indicates that experts' ratings for one dimension increases, for second increases as well. Therefore referring to that it could be noticed that experts' agreed that both Asymmetric information and Irresponsible lending were the most important preconditions for credit shocks in Lithuania.

The structural changes in financial markets in terms of introducing new financial instruments also has significant quite strong monotonic association (Spearman's rho 0.764, $p=0.017$ ) with Asymmetric information. And it is not surprising that there was found a strong positive monotonic relationship (Spearman's rho 0.899, $p=0.001$ ) between globalisation of financial markets and structural changes in financial markets. To illustrate, Schnabl (2008) contend that "The increasing globalization of financial and banking markets provides important advantages in terms of diversification and efficiency gains. However, the globalization of financial markets also creates possible channels for the transmission of financial shocks across markets."

Question block regarding the outcomes of credit shocks involve 14 items. A modest and significant compatibility among experts' ratings have been found, as it is indicated by Kendall concordance coefficient value $(\mathrm{W}=0.594)$ and $\mathrm{p}$ value $(0.000<0.05)$, meaning that there is significant difference among ranks presented in figure 4 .

According to the Kendall concordance test, experts unanimously identified the primary consequences of credit shock and 2007-2009 crisis in Lithuania (figure 4), including Decrease in GDP and government revenues (mean rank of 11.56), Fall in domestic demand in Lithuania and increase in importance of exports for economic development (mean rank of 11.11), The decline in consumption level and the delay of purchase (mean rank of 10.56), Shrinkage of construction sector, and manufacturing and trade of durable goods (mean rank of 9.94).

Even more descriptive statistics have indicated that the minimum score for these four statements were rated of highest scores (four and five), which means the full consent and agreement with the statements.

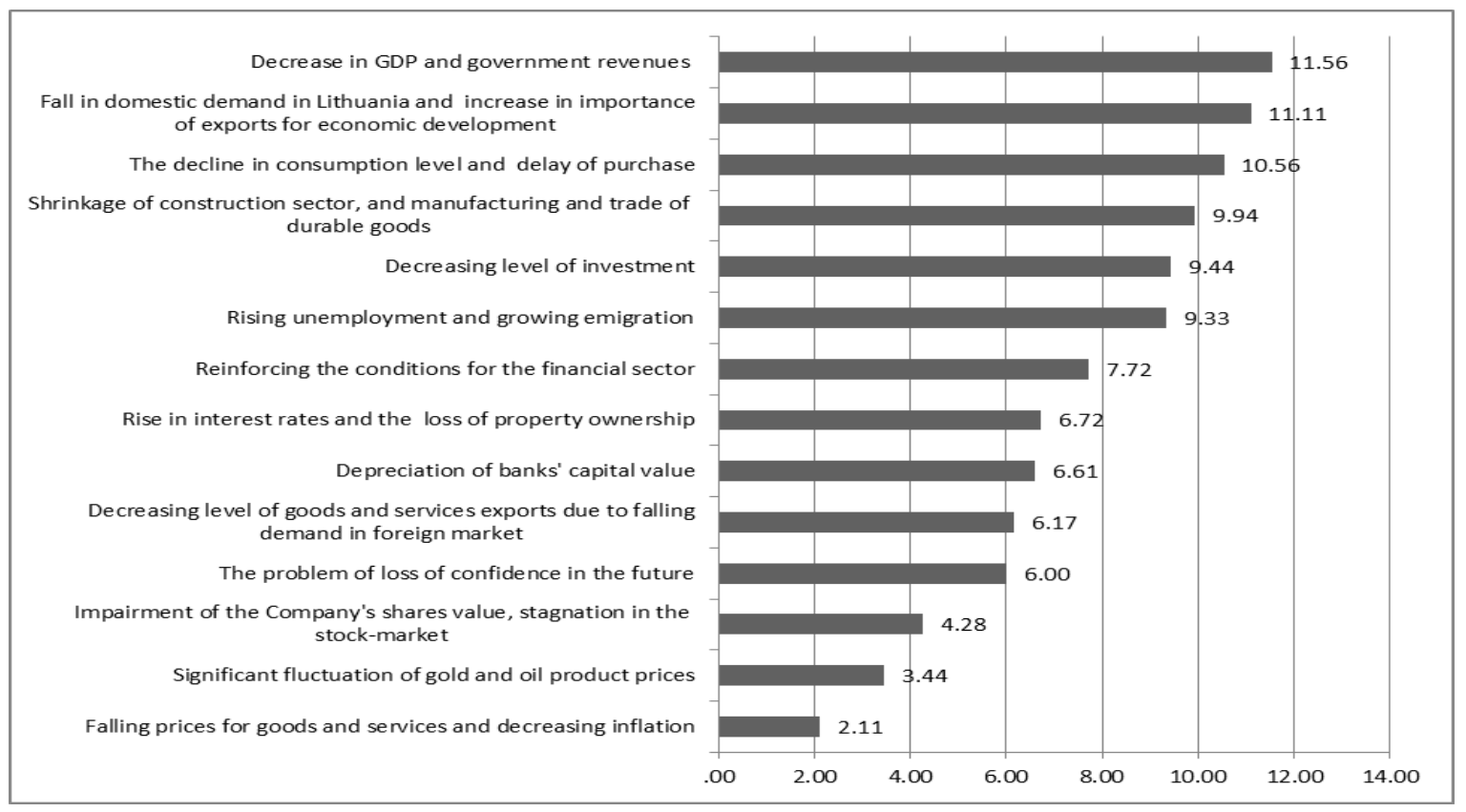

Figure 4. Mean ranks for statements indicating consequences of credit shocks and 2007-2009 crisis

Meanwhile as indicating by mean ranks (figure 4) significant fluctuations of gold and oil prices and decreasing inflation are least important consequences of credit shocks and financial crisis in Lithuania.

Whilst analysing the correlation the significant monotonic relations have occurred and are presented in table 3 .
Table 3

Correlation among the consequences (Spearman's rho)

\begin{tabular}{|l|c|}
\hline \multirow{2}{*}{$\begin{array}{l}\text { Rise in interest rates and the loss of } \\
\text { property ownership }\end{array}$} & $\begin{array}{c}\text { The decline in consumption } \\
\text { level and the delay of } \\
\text { purchase Correlation } \\
\text { Coefficient, Sig. (2-tailed) }\end{array}$ \\
\cline { 2 - 2 } $\begin{array}{l}\text { Shrinkage of construction sector, and } \\
\text { manufacturing and trade of durable goods }\end{array}$ & $\mathbf{0 . 7 0 4}{ }^{*}$ \\
\cline { 2 - 2 } $\begin{array}{l}\text { Fall in domestic demand in Lithuania and } \\
\text { increase in importance of exports for } \\
\text { economic development }\end{array}$ & $\mathbf{0 . 7 9 1}$ \\
\cline { 2 - 2 } & $\mathbf{0 . 0 1 1}$ \\
\hline
\end{tabular}

** Correlation is significant at the 0.01 level (2-tailed).

* Correlation is significant at the 0.05 level (2-tailed). 
It has been found that decreasing consumption level is significantly associated with increasing interest rates and loss of property's ownership; also with contraction in construction and sales sectors as well as with Decrease in domestic demand and increase in importance of exports in Lithuania's economic development. This indicates that experts' equally rated the statements and agreed that all mentioned statements were important consequences for credit shock and financial crisis in Lithuania.

To sum up, literature review indicate that due to financial crisis there was conspicuous decrease in many scopes of economic activities for instance decrease of consumption, increase of unemployment and therefore the engine of economy has stopped and the chain of various effects caused the deep recession and long an slow recovery of economies. Therefore to overcome such negative effect macroprudencial measures need to be discussed.

For expert assessment fourteen statements regarding the policy measures were given. Kendalls' tests statistics for rated statements. Indicates a weak agreement among experts was identified although significant $(\mathrm{W}=0.308 \mathrm{p}<$ $0.05)$. Thus there is the significant difference among ranks (see figure 5).

Figure 5 indicates that according to expert assessment the most important policy measure in mitigating financial crisis consequences is related to tightening requirements for capital and reserves of the authority issuing credits (mean rank of 10.56).

On overall the descriptive statistics indicates that for all statements, except for credible exit strategy, the mean score is above the 3.5 threshold meaning experts agree with the statements.

According to experts' evaluation results to ensure responsible borrowing is a second important issue (mean rank of 9.67) in mitigating credit shocks and financial crisis.

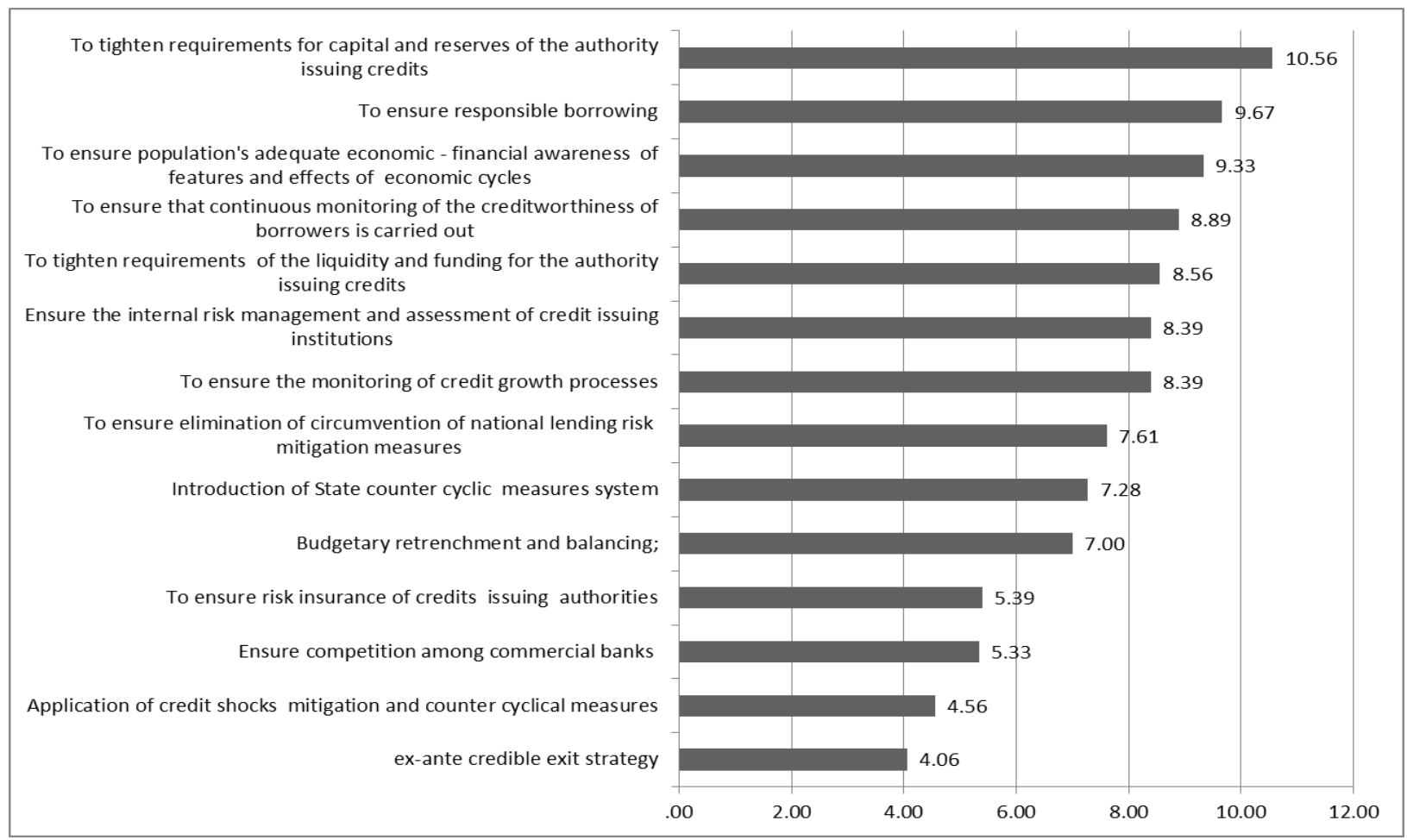

Figure 5. Mean ranks for statements indicating policy measures in mitigating crisis consequences

Also experts' opinion evaluation indicate that it is important to ensure population's adequate economic financial awareness of features and effects of economic cycles (mean rank of 9.33)

Moreover expert evaluation research has revealed that the least important measures for mitigating credit shocks and financial crisis include preparation of ex-ante credible exit strategy (mean rank of 4.06) and application of credit shocks mitigation and counter cyclical measures (mean rank of 4.56).

\section{Conclusions}

More precisely, literature review indicates effects of recent financial crisis at macro and micro level perspective.
Macro-level effects include the decrease in consumption, aggregate demand and investment, financial markets stagnation, increase in Government debt and unemployment rate and even more political instability.

While effects at macro level encompass the decline in business loans, fall in equity valuation, property devaluation, decrease in sales, increase in defaults, decrease in investment in R\&D and etc. Following the theoretical research framework the instrument was prepared and experts' evaluation research was organized.

Expert evaluation results indicate that absence of reserve funds was the most important precondition for 2007-2009 financial crisis. Additionally, when the gathered unplanned cyclical income have been wasted and even the public sector spending has been increased that led to even 
bigger budget deficit and therefore long recovery process. This situation was observed also in other countries like Greece and Spain.

Also experts unanimously identified the main consequences of credit shock and 2007-2009 crisis including: (1) Decrease in GDP and government revenues, (2) Fall in domestic demand in Lithuania and increase in importance of exports for economic development, (3) The decline in consumption level and the delay of purchase, and
(4) Shrinkage of construction sector, and manufacturing and trade of durable goods.

Regarding the policy issues and recommendations, according to expert evaluation results, the most important policy measures in mitigating financial crisis consequences is related to tightening requirements for capital and reserves of the authority issuing credits and ensuring responsible borrowing.

\section{References}

Amiti, M., \& Weinstein, D. E. (2013). How Much do Bank Shocks Affect Investment? Evidence from Matched Bank-Firm Loan Data. January 28, 2013. Available from internet: https://groups.gsb.columbia.edu/uploaD/doc_212574_ amitiweinsteinhow_much_do_bank_shocks_affect_investment_28144733.pdf

Barnett, A., \& Thomas, R. (2013). Has weak lending and activity in the United Kingdom been driven by credit supply shocks? Working Paper No. 482. Available from internet: Http:/Www.Bankofengland.Co.Uk/Research/Documents/ Workingpapers/2013/Wp482.Pdf

Bassett, W. F., Chosak, M. B., Driscoll, J. C., \& Zakrajsek, E. (2013). Changes in bank lending standards and the macroeconomy. http://dx.doi.org/10.1016/j.jmoneco.2013.12.005

Bedock, N., \& Stevanovic, D. (2012). Empirical study of credit shock transmission in a small open economy. Max Weber Programme, EUI Working Papers MWP 2012/02. [Online] Available from internet: http://cadmus.eui.eu/bitstream/ handle/1814/21741/MWP_2012_02_Stevanovic.pdf?sequence=1

Bezemer, D. J. (2009). No One Saw This Coming": Understanding Financial Crisis Through Accounting Models. MPRA Paper No. 15892. Available from internet: http://mpra.ub.uni-muenchen.de/15892/1/MPRA_paper_15892.pdf

Calaguas, G. M., \& Dizon, C. S. (2011). Development and Initial Validation of the Social Competency Inventory for Tertiary Level Faculty Members. International Journal of Human and Social Sciences 6(3) 2011. Available from internet: <http://www.waset.org/journals/ijhss/v6/v6-3-25.pdf>.

Carnot, N., Koen,V., \& Tissot, B. (2011). Financial sector dynamics. In N. Carnot, V. Koen, B. Tissot (Eds) Economic forecasting and policy (Second edition). Palgrave Macmillan

Claessens, S., Tong, H., \& Zuccardi, I. (2012). Saving the Euro: Mitigating Financial or Trade Spillovers? Available from internet: http://www.cass.city.ac.uk/_data/assets/pdf_file/0008/127493/Zuccardi.pdf

Cohan, P. (2010). How to prevent another Financial Crisis? Available from internet: http://www.dailyfinance.com/ 2010/03/29/how-to-prevent-another-financial-crisis-make-wall-street-pay/

Eickmeier, S., \& Ng, T. (2011). How do credit supply shocks propagate internationally? A GVAR approach. Discussion Paper Series 1: Economic Studies No. 27/2011. Available from internet: http://www.bundesbank.de/Redaktion/EN/ Downloads/Publications/Discussion_Paper_1/2011/2011_12_12_dkp_27.pdf?_blob=publicationFile

Federal Reserve Bank of New York. (2010). Tools for Mitigating Credit Risk in Foreign Exchange Transactions. Available from internet: http://www.newyorkfed.org/fxc/2010/creditrisktools.pdf

Field, A. (2009). Discovering Statistics Using SpSS. 3rd edition. Sage.

Finansu ministerija. (2011). Finansu skola 2011. Available from internet: http://www.finmin.lt/finmin.lt/failai/leidiniai/ failai/fm_valstybes_skola_2011.pdf

Fornari, F., \& Stracca, L. (2011). What does a financial shock do? First international evidence. Available from internet http://www.bis.org/events/bokbisimf2012/session2_what_does_a_financial_shock_do.pdf

Friese, S. (2011). Using ATLAS.ti for Analyzing the Financial Crisis Data $[67$ paragraphs]. Forum Qualitative Sozialforschung / Forum: Qualitative Social Research, 12(1), Art. 39, Available from internet: http://nbnresolving.de/urn:nbn:de:0114-fqs1101397

George, D., \& Mallery, P. (2003). SPSS for Windows step by step: A simple guide andreference. 11.0 update (4th ed.). Boston: Allyn \& Bacon.

Gianone, D., Lenza, M., Pill, H., \& Reichlin, L. (2011). Non-standard Monetary Policy Measures and Monetary Developments. Working Paper No. 1290. European Central Bank Working Paper Series. Available from internet: http://www.ecb.europa.eu/pub/pdf/scpwps/ecbwp1290.pdf

Gilchrist, S., \& Zakrajsek, E. (2012). Credit Supply Shocks and Economic Activity in a Financial Accelerator Model, April 10, 2012. Available from internet: http://people.bu.edu/sgilchri/research/Russell_Sage_GZ_09Apr2012.pdf

Gilchrist, S., Yankov, V., \& Zakrajsek, E. (2009). Credit Market Shocks and Economic Fluctuations: Evidence from Corporate Bond and Stock Markets. Journal of Monetary Economics, Elsevier, 56(4).

Greenstone, M., \& Mas, A. (2012). Do Credit Market Shocks affect the Real Economy? Quasi-Experimental Evidence from the Great Recession and 'Normal' Economic Times. Working Paper 12-27. Massachusetts Institute of Technology. Available from internet: 〈http://papers.ssrn.com/sol3/papers.cfm?abstract_id=2187521〉. 
Ho, M. (2010). Mitigating Downside Risks from Market Shocks. Available from internet: http://us.bnymellonam.com/core/ library/documents/knowledge/AssetAllocation/mitigating_risk_052010.pdf

Jermann, U., \& Quadrini, V. (2012). Macroeconomic Effects of Financial Shocks. American Economic Review, American Economic Association, 102(1), p. 238-71, February.

Keen, S. (2013). Predicting the 'Global Financial Crisis': Post-Keynesian Macroeconomics. Economic Record, 89(285), June, 2013, 228-254.

Khan, A., \& Thomas, J. K. (2013). Credit Shocks and Aggregate Fluctuations in an Economy with Production Heterogeneity. Available from internet: http://juliathomas.net/KhanThomasDCTsept2013.pdf

Lagarde, Ch. (2011). How The G20 can prevent another Financial Crisis. Available from internet: http://www.ft.com/intl/ $\mathrm{cms} / \mathrm{s} / 0 / 3172 \mathrm{c} 19 \mathrm{c}-2556-11 \mathrm{e} 0-93 \mathrm{ae}-00144 \mathrm{feab49a.html \# axzz2PrxEQZT} 5$

Liberti, J. M., \& Sturgess, J. (2013). The Anatomy of a Credit Supply Shock: Evidence from an Internal Credit Market. Jan 25, 2013. Available from internet: https://www.tilburguniversity.edu/upload/7e1330b8-1bc1-498d-9222-c7707ec9 d174_liberti.pdf

Lutkepohl, H. (2012). Fundamental Problems with Nonfundamental Shocks. DIW Berlin German Institute for Economic Research Discussion Papers no. 1230. Available from internet: http://www.wiwiss.fu-berlin.de/fachbereich/ vwl/luetkepohl/Forschung/DIW_working_paper/dp1230.pdf?1357642459

MacCarthy, B. L., \& Atthirawong, W. (2003). Factors affecting location decisions in international operations - a Delphi study. International Journal of Operations \& Production Management, 23, pp.794-818.

Maredza, A., \& Ikhide, S. (2013). Measuring the Impact of the Global Financial Crisis on Efficiency and Productivity of the Banking System in South Africa. Mediterranean Journal of Social Sciences, 4(6). Doi: 10.5901/mjss.2013.v4n6p553

Meeks, R. (2009). Credit Market Shocks: Evidence from Corporate Spreads and Defaults. Federal rezerve Bank of Dallas, Research Department Working paper 0906. First draft. Available from internet: http://dallasfed.org/assets/ documents/research/papers/2009/wp0906.pdf

Paravisini, D., Rappoport, V., Schnabl, Ph., \& Wolfenzon, D. (2010). Dissecting the Effect of Credit Supply on Trade: Evidence fromMatched Credit-Export Data. BANCO CENTRAL DE RESERVA DEL PERÚ. Working Paper series DT. N 2010-022. Available from internet: http://www.bcrp.gob.pe/docs/Publicaciones/Documentos-deTrabajo/2010/Documento-de-Trabajo-22-2010.pdf

Pesaran, M. H., \& Xu, T. (2013). Business Cycle Effects of Credit Shocks in a DSGE Model with Firm Defaults. [Online] Available from internet: http://www.econ.cam.ac.uk/emeritus/pesaran/wp13/MacroCredit_PesaranXu-Feb-2013.pdf.

Raja Prasad, S. V. S., \& Reghunath, K. P. (2010). Empirical Analysis of Construction Safety Climate - A Study. International Journal of Engineering Science and Technology, 2(6), 2010, 1699-1707.

Schmidt, R. C. (1997), Managing Delphi Surveys Using Nonparametric Statistical Techniques. Decision Sciences, 28: 763774. doi: 10.1111/j.1540-5915.1997.tb01330.x

Schnabl, Ph. (2008). Financial Globalization and the Transmission of Credit Supply Shocks: Evidence from an Emerging Market. Available from internet: http://archive.nyu.edu/bitstream/2451/27850/2/wpa08008.pdf

Sheskin, D. J. (2000). Handbook of Parametric and Nonparametric Statistical Procedures. 2nd Edition. Chapman \& Hall/CRC.

Tracey, M. (2007). A VAR Analysis of the Effects of Macroeconomic Shocks on Banking Sector Loan Quality in Jamaica. Available from internet: http://boj.org.jm/uploads/pdf/papers_pamphlets/papers_pamphlets_A_VAR_Analysis_of_ the_Effects_of_Macroeconomic_Shocks_on_Banking_Sector_Loan_Quality.pdf

Umbrasiene, G. (2014). Analysis of Cyclical Sensitivity in Traditional and New Sectors: the Case of Lithuanian Economy. Inzinerine Ekonomika-Engineering Economics, 25(4), 420-426. http://dx.doi.org/10.5755/j01.ee.25.4.2055

Vogt, P. W., \& Johnson, R. B. (2011). Dictionary of Statistics \& Methodology: A Nontechnical Guide for the Social Sciences. Sage, 456 psl. Available from internet: http://books.google.lt/books?id=rDib3X4YsSQC\&dq=Kendall+ coefficient+validity+in+social+science $\& 1 \mathrm{r}=\&$ source=gbs_navlinks_s

Yang, Y., \& Green, S. B. (2011). Coefficient Alpha: A Reliability Coefficient for the 21st Century? Journal of Psychoeducational Assessment 29, 377 originally published online 19 May 2011, Doi: 10.1177/0734282911406668.

The article has been reviewed.

Received in January 2015; accepted in February, 2016. 